\title{
Dietary Fiber Content of Waterleaf (Talinum triangulare (Jacq.) Willd) Cultivated with Organic and Conventional Fertilization in Different Seasons
}

\author{
Nuri Andarwulan1,2, Didah Nur Faridah'1,2, Yolanda Sylvia Prabekti1, \\ Harum Fadhilatunnur'1, Leo Mualim ${ }^{3}$, Sandra Arifin Aziz ${ }^{3}$, Luis Cisneros-Zevallos ${ }^{4}$ \\ ${ }^{1}$ Department of Food Science and Technology, Bogor Agricultural University, Bogor, Indonesia \\ ${ }^{2}$ Southeast Asian Food and Agricultural Science and Technology (SEAFAST) Center, Bogor Agricultural \\ University, Bogor, Indonesia \\ ${ }^{3}$ Department of Agronomy and Horticulture, Bogor Agricultural University, Bogor, Indonesia \\ ${ }^{4}$ Department of Horticultural Sciences, Texas A\&M University, College Station, USA \\ Email: nuri@seafast.org
}

Received 15 December 2014; accepted 7 February 2015; published 12 February 2015

Copyright (C) 2015 by authors and Scientific Research Publishing Inc.

This work is licensed under the Creative Commons Attribution International License (CC BY).

http://creativecommons.org/licenses/by/4.0/

(c) (i) Open Access

\section{Abstract}

Waterleaf (Talinum triangulare (Jacq.) Willd has long been eaten in Indonesia as vegetable and the main parts consumed are leaves and young shoots. Waterleaf is sticky presumably due to its pectin content which is associated to dietary fiber. The dietary fiber which was analyzed in the present study was influenced by cultivation practices. The aim of this research was to study the effect of organic and conventional fertilization as well as the seasonal changes to the level of TDF (total dietary fiber), IDF (insoluble dietary fiber), SDF (soluble dietary fiber), and pectic substances in waterleaf. This research was conducted in four phases: sample cultivation, sample preparation, chemical analysis, and data analysis. This research used five samples cultivated with $\mathbf{5}$ different compositions of organic fertilizers and vice versa for conventional fertilizers. The cultivation was done in the experimental field of University Farm, Bogor, Indonesia during rainy season and dry season. Samples were harvested 8 weeks after planted, dried using drying oven for 17 hours at $60^{\circ} \mathrm{C}$, ground and filtered to $40 \mathrm{mesh}$; and kept at $-10^{\circ} \mathrm{C}$ until analysis. The overall result showed that the conventional samples contain higher dietary fiber than the organically fertilized samples, except the pectic substances of plant in dry season. Although its IDF content is higher than the SDF, the SDF content of waterleaf is relatively high compared to other vegetables, especially in dry season. 


\section{Keywords}

\section{Total Dietary Fiber, Soluble Dietary Fiber, Insoluble Dietary Fiber, Pectic Substances}

\section{Introduction}

Waterleaf (Talinum triangulare (Jacq.) Willd) has long been eaten in Indonesia as vegetable and the main parts consumed are leaves and young shoots. It contains a sticky substance that is presumably due to its pectin content which is associated to dietary fiber. Waterleaf is also an important source of phenolic antioxidants [1]. The dietary fiber which was analyzed in the present study as influenced by cultivation practices.

Fertilization may be applied in organic and conventional practices which have been reported to influence a broad range of chemical constituents. Several studies have shown higher polyphenol content [2]-[5] and antioxidant activity [6] in organic plants compared to conventional grown plants. Furthermore, trends of higher content of vitamin C, iron, magnesium, and phosphorus [7] and sugar [8] and lower levels of nitrates [2] [9] have also been reported. As plants grow, nutrients in soil are reduced, therefore the addition of fertilizer in the form of organic or conventional is important to maintain the soil fertility.

Another cultivation practice that will affect plant growth and chemical constituents is the selection of the growing season, such as a rainy or dry season. For example, dietary fiber content in plants has been associated to seasonal changes [10] [11] while the synthesis of secondary metabolites has been associated to environmental changes, including temperature changes between day and night, rainfall, drought, and sunlight intensity [12][14]. Reference [14] reported that waterleaf dry season crops showed high content of phenolic compound but low level of PAL (phenylalanine ammonia lyase) and low level of chlorophyl. This suggest that phenolic compounds were synthesized through the malonic acid pathway rather than the phenilpropanoid. This pathway uses acetyl coenzyme A as a precursor, causing substrate competition with the chlorophyl synthesis pathway, since both are using the same precursor. As the chlorophyl level decreased in the dry season, the photosynthesis process was affected decreasing the products of photosynthesis and affecting the synthesis of other compounds, such as dietary fiber.

Thus, in the present study, we characterized the dietary fiber constituents of waterleaf as influenced by cultivation practices including a comparison between organic and conventional fertilization as well as the influence of a rainy and dry growing season conditions.

\section{Method}

\subsection{Chemical and Reagent}

Ethanol, acetone, phosphate buffer pH 6.0, $\mathrm{NaOH}, \mathrm{HCl}$, celite C-211, $\mathrm{K}_{2} \mathrm{SO}_{4}, \mathrm{HgO}, \mathrm{H}_{2} \mathrm{SO}_{4}, \mathrm{NaOH}, \mathrm{H}_{3} \mathrm{BO}_{3}$, EDTA-4Na, $\mathrm{H}_{2} \mathrm{SO}_{4}$, o-hydroxydiphenyl, $\mathrm{NaOH}, \mathrm{Na}_{2} \mathrm{~B}_{4} \mathrm{O}_{7}$, Na-oxalate (p.a E.Merck), distilled water, Termamyl (120 L, Novo Laboratories), protease (P-3910, Sigma Chemical), amyloglucosidase (A-9913, Sigma Chemical), viscozyme (V-2010, Sigma Chemical), galacturonic acid standard (Sigma Chemical).

\subsection{Sample Cultivation}

Samples used in this research included 5 samples cultivated with organic fertilizer (Table 1) and 5 samples cultivated with conventional fertilizer (Table 2). The plants were cultivated in the different seasons, i.e. rainy season (February-April) and dry season (May-July). The plants were harvested after 8 weeks, it was taken three replication for dietary fiber and pectic substances analysis to obtain representative data.

Dung contains N level of $1.29 \%$ with $71 \%$ of moisture content in wet basis. Guano contains P level of $10.43 \%$ in the form of $\mathrm{P}_{2} \mathrm{O}_{5}$ with $8.69 \%$ of moisture content, and husk ash contains $\mathrm{K}$ level of $1.10 \%$ in the form of $\mathrm{K}_{2} \mathrm{O}$. The dose of each element ( $\mathrm{N}, \mathrm{P}$, and $\mathrm{K}$ ) was obtained by multiplying the amount of fertilizer $(\mathrm{kg} / \mathrm{ha})$ in each treatment with the percentage of each element, except for the $\mathrm{n}$ element, there was a slightly different calculation because the fertilizer has moisture vontent of $71 \%$. Example of calculations in organic treatment 1 :

- dose of N element: $(100-71) \% \times 1.29 \% \times 6.1 \mathrm{ton} / \mathrm{ha}=22.82 \mathrm{~kg} / \mathrm{ha}$;

- dose of P element (in the form of $\left.\mathrm{P}_{2} \mathrm{O}_{5}\right)$ : $(100-8.69) \% \times 10.43 \% \times 75.6 \mathrm{~kg} / \mathrm{ha}=7.20 \mathrm{~kg} / \mathrm{ha}$; 
Table 1. Treatment of organic fertilizer.

\begin{tabular}{ccccccc}
\hline Treatment & Dung (ton/ha) & $\mathrm{N}$-dose $(\mathrm{kg} / \mathrm{ha})$ & $\mathrm{Guano}(\mathrm{kg} / \mathrm{ha})$ & $\mathrm{P}_{2} \mathrm{O}_{5}$-dose $(\mathrm{kg} / \mathrm{ha})$ & Husk ash (ton/ha) & $\mathrm{K}_{2} \mathrm{O}-\mathrm{dose}(\mathrm{kg} / \mathrm{ha})$ \\
\hline Organic 1 & 6.1 & 22.82 & 75.6 & 7.20 & 2.7 & 29.70 \\
Organic 2 & 9.2 & 34.42 & 151.2 & 14.40 & 4.1 & 45.10 \\
Organic 3 & 12.3 & 46.01 & 226.8 & 21.60 & 5.5 & 60.50 \\
Organic 4 & 15.4 & 57.61 & 302.4 & 28.80 & 6.8 & 74.80 \\
Organic 5 & 18.4 & 68.83 & 378 & 35.99 & 8.2 & 90.20 \\
\hline
\end{tabular}

Table 2. Treatment of conventional fertilizer.

\begin{tabular}{|c|c|c|c|c|c|c|}
\hline Treatment & Urea (kg/ha) & N-dose (kg/ha) & SP-36 (kg/ha) & $\mathrm{P}_{2} \mathrm{O}_{5}$-dose $(\mathrm{kg} / \mathrm{ha})$ & $\mathrm{KCl}$ (kg/ha) & $\mathrm{K}_{2} \mathrm{O}$-dose (kg/ha) \\
\hline Conventional 1 & 50 & 23.00 & 20 & 7.20 & 50 & 30.00 \\
\hline Conventional 2 & 75 & 34.50 & 40 & 14.40 & 75 & 45.00 \\
\hline Conventional 3 & 100 & 46.00 & 60 & 21.60 & 100 & 60.00 \\
\hline Conventional 4 & 125 & 57.50 & 80 & 28.80 & 125 & 75.00 \\
\hline Conventional 5 & 150 & 69.00 & 100 & 36.00 & 150 & 90.00 \\
\hline
\end{tabular}

- dose of K element (in the form of $\left.\mathrm{K}_{2} \mathrm{O}\right):(1.10 \% \times 2.7)$ ton $/ \mathrm{ha} \times 1000=29.70 \mathrm{~kg} / \mathrm{ha}$.

Urea contains $\mathrm{N}$ level of $46 \%$, SP-36 contains $\mathrm{P}$ level of $36 \%$ in the form of $\mathrm{P}_{2} \mathrm{O}_{5}, \mathrm{~K}_{2} \mathrm{O}$ fertilizer contains $\mathrm{K}$ level of $60 \%$. The dose of each element $(\mathrm{N}, \mathrm{P}$, and $\mathrm{K}$ ) was obtained by multiplying the amount of fertilizer $(\mathrm{kg} / \mathrm{ha})$ in each treatment with the percentage of each element. Example given for conventional 1 treatment:

- dose of N element: $46 \% \times 50 \mathrm{~kg} / \mathrm{ha}=23 \mathrm{~kg} / \mathrm{ha}$;

- dose of P element (in the form of $\mathrm{P}_{2} \mathrm{O}_{5}$ ): $36 \% \times 20 \mathrm{~kg} / \mathrm{ha}=7.20 \mathrm{~kg} / \mathrm{ha}$;

- dose of K element (in the form of $\mathrm{K}_{2} \mathrm{O}$ ): $60 \% \times 50 \mathrm{~kg} / \mathrm{ha}=30 \mathrm{~kg} / \mathrm{ha}$.

\subsection{Sample Preparation}

Edible portion of the sample, which is about $15 \mathrm{~cm}$ from the top was obtained from the harvested 8 weeks old plants. Then, samples selection was performed as an initial step to obtain representative and uniform samples. The sample were cleaned and divided into wet samples and dried samples. The moisture content of wet samples was then analyzed. Most of the other samples were then dried with drying oven for 17 hours at $60^{\circ} \mathrm{C}$. Dried samples was ground to 40 mesh to obtain powder leaves. Water content, dietary fiber, and pectic substances of the dried sample were then analyzed. Moisture content of fresh and dried samples are determined by oven method [15].

\subsection{Dietary Fiber Analysis}

Total dietary fiber content analysis was determined using the gravimetric method [16]. All procedures are also performed on the blank to see if there are deposits of non-fibers derived from reagents or enzymes remaining in the residue and can be counted as dietary fiber. About $0.5 \mathrm{mg}$ of sample was weighed in $200 \mathrm{ml}$ of beaker glass. Then, $25 \mathrm{ml}$ of phosphate buffer $\mathrm{pH} 6.0$ was inserted into the beaker glass, $\mathrm{pH}$ value was adjusted to $6.0 \pm 0.2$. After that, $0.05 \mathrm{ml}$ of termamyl added. Then, the beaker glass was closed using aluminum foil paper (alufo) and was placed in boiling water for 15 minutes, shaken slowly in every 5 minutes. The heating time can be added until 30 minutes to reach an internal temperature between $95^{\circ} \mathrm{C}-100^{\circ} \mathrm{C}$. Subsequently, the solution was cooled at room temperature, $\mathrm{pH}$ value was adjusted to $7.5 \pm 0.2$ with $\mathrm{NaOH} 0.275 \mathrm{~N}$. Then, $2.5 \mathrm{mg}$ of protease was added into the sample. Protease can also be used in the form of solution (50 $\mathrm{mg}$ in $1 \mathrm{ml}$ phosphate buffer), was pipetted as much as $0.05 \mathrm{ml}$ and was put into the sample just before used.

Recovered sample was then incubated for 30 minutes at $60^{\circ} \mathrm{C}$ with continuous agitation. The sample was cooled and was added with $5 \mathrm{ml} \mathrm{HCl} 0.325 \mathrm{~N}$, pH value was measured to 4.0 - 4.6. If the $\mathrm{pH}$ value has not 
reached, more acid can be added. A $0.15 \mathrm{ml}$ of amyloglucosidase enzyme (AMG) was added, and then the sample was recovered with alufo, was incubated for 30 minutes at $60^{\circ} \mathrm{C}$ with continuous agitation. A $140 \mathrm{ml}$ of ethanol $95 \%$ which had previously been heated to $60^{\circ} \mathrm{C}$ (volume was measured after heating) was added to form the precipitation. Sample was left at room temperature for 60 minutes. The precipitate was then filtered quantitatively through the crucible. Previously, the crucible and its celite were weighed to the accuracy close to $0.1 \mathrm{mg}$.

The residue was washed with $3 \times 5 \mathrm{ml}$ of ethanol $78 \%, 2 \times 5 \mathrm{ml}$ of ethanol $95 \%$, and $2 \times 5 \mathrm{ml}$ of acetone, respectively. Some samples can form resin. Filtration may be assisted by stirring using a spatula. The time needed for washing and filtration can be varied from 0.1 to 6 hours, the average time taken is 20 minutes per sample. The length of time can be reduced by using vacuum suction during filtration. Crucible containing the residue was then dried overnight in a drying oven at $105^{\circ} \mathrm{C}$, and then it was cooled in desiccators and was weighed to the accuracy reached $0.05 \mathrm{mg}$. To obtain residue weight, subtract with the weight of crucible and celite.

Residue analysis of one replicate was then used for protein analysis using the Kjeldahl method. The conversion factor used is $\mathrm{N} \times 6.25$. Another sample test was then burned for 5 hours at $475^{\circ} \mathrm{C}$ to obtain ash weight, and then cooled in desiccators and was weighed to the accuracy close to $0.1 \mathrm{mg}$. Subtract of crucible and celite to obtain ash weight.

The procedure performed for insoluble dietary fiber analysis [17] was closely similar with total dietary fiber analysis until quantitatively sample filtration step into the crucible. Subsequently, the residue was washed with 2 $\times 5 \mathrm{ml}$ of water (to dissolve SDF), $2 \times 5 \mathrm{ml}$ of ethanol $95 \%$, and $2 \times 5 \mathrm{ml}$ acetone, respectively. The steps for drying crucible until the final stage of the procedure are similar to the total dietary fiber. Determination of soluble dietary fiber was done by subtracting the content of total dietary fiber with the content of insoluble dietary fiber.

\subsection{Pectic Substances Analysis}

Pectic substances is calculated based on colorimetric method of [18] which has been modified by [19]. Anhydrogalacturonic obtained from the hydrolysis of the substances together with o-hydroxydiphenyl will produce color that can be measured at $520 \mathrm{~nm}$.

\subsection{Data Analysis}

Data are presented as the mean \pm standard deviation of at least triplicate determinations. Statistical significance was by one-way ANOVA and student t-test, with $\mathrm{p}$ value $\leq 0.05$ considered significant.

\section{Results}

\subsection{Dietary Fiber Content and Growing Season Effects}

In conventional fertilized waterleaf, TDF showed distinct ranges between the rainy and dry season crops ranging in values of $~ 74-81$ and 39 - $44 \mathrm{~g} / 100 \mathrm{~g} \mathrm{dw}$, respectively. Similar trend was observed for IDF between rainy and dry season crops with range values of $\sim 69$ - 76 and 26 - $28 \mathrm{~g} / 100 \mathrm{~g} \mathrm{dw}$, respectively, however, this trend was reversed in SDF showing range values of $\sim 4.6$ - 5.8 and 13 - $17 \mathrm{~g} / 100 \mathrm{~g} \mathrm{dw}$, respectively. In general there was no clear trend between the different doses used in conventional fertilization and the observed values corresponding to TDF, IDF and SDF (Table 3).

When comparing the average values of all conventional fertilized treatments we observe that values for TDF and IDF in rainy season crop $>$ dry season crops $(p<0.05)$. However, for SDF values results indicate that rainy season crops $<$ dry season crops $(\mathrm{p}<0.05)$ (Figure 1$)$.

On the other hand, in organic fertilized waterleaf, TDF also showed distinct ranges between the rainy and dry season crops ranging in values of $\sim 63-79$ and $36-42 \mathrm{~g} / 100 \mathrm{~g} \mathrm{dw}$, respectively. Similar trend was observed as well for IDF between rainy and dry season crops with range values of $~ 59-74$ and 25 - $28 \mathrm{~g} / 100 \mathrm{~g} \mathrm{dw}$, respecttively, however, once again this trend was reversed in SDF showing range values of $\sim 4.4-4.7$ and $11-15$ $\mathrm{g} / 100 \mathrm{~g} \mathrm{dw}$, respectively. Like in conventional fertilization there was no clear trend between different doses used in organic fertilization and the observed values corresponding to TDF, IDF and SDF (Table 3).

When comparing the average values of all organic fertilized treatments we observe that values for TDF and 


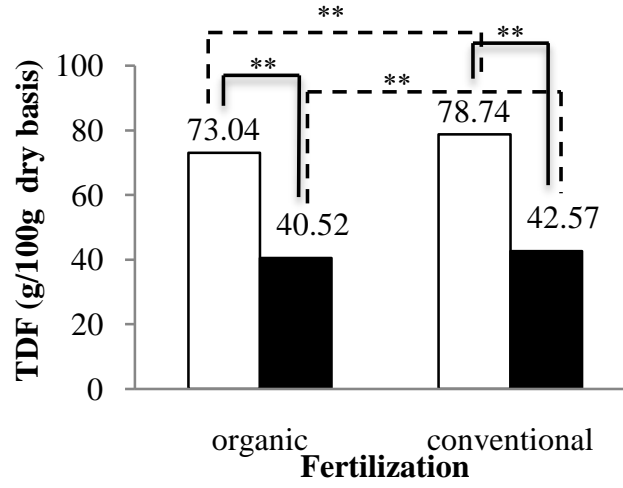

(a)

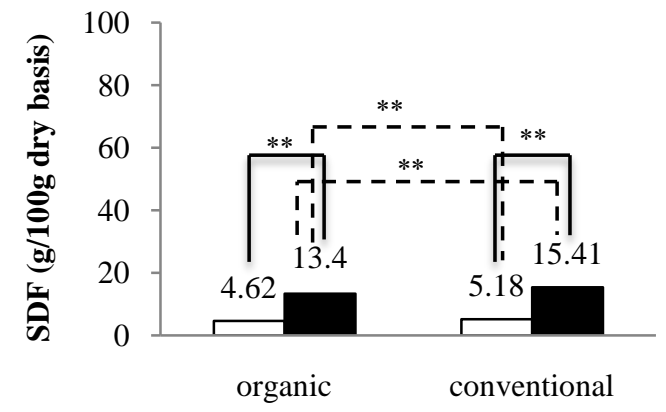

Fertilization

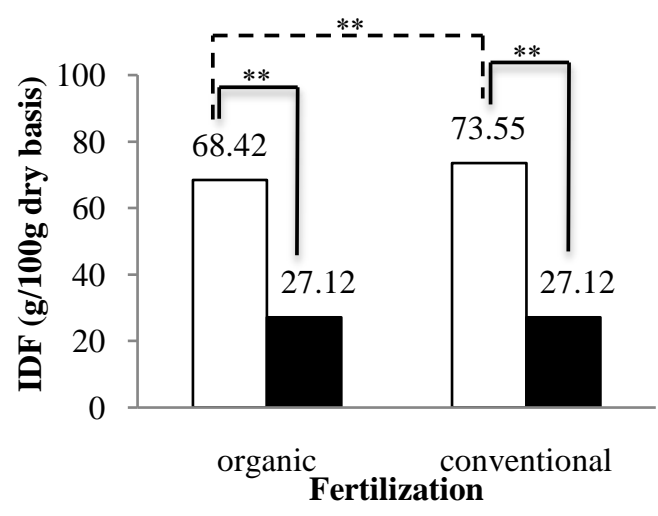

(b)

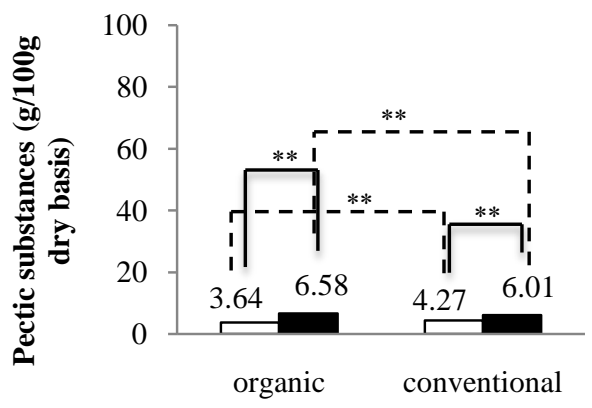

Fertilization

: dry season $\quad{ }^{* *}$ : significant different $(\mathrm{p}<0.05)$

(c)

Figure 1. Dietary fiber profile of waterleaf that were cultivated using organic and conventional fertilization at different season (a) TDF; (b) IDF; (c) SDF; and (d) pectic substances.

Table 3. Dietary fiber content of Talinum triangulare (Jacq.) Willd in dry weight.

\begin{tabular}{ccccccc}
\hline \multirow{2}{*}{ Fertilizer } & \multicolumn{2}{c}{ TDF $(\mathrm{g} / 100 \mathrm{~g} \mathrm{dw})$} & \multicolumn{2}{c}{ IDF $(\mathrm{g} / 100 \mathrm{~g} \mathrm{dw})$} & \multicolumn{2}{c}{ SDF $(\mathrm{g} / 100 \mathrm{~g} \mathrm{dw})$} \\
\cline { 2 - 6 } & Rainy season & Dry season & Rainy season & Dry season & Rainy season & Dry season \\
\hline Conventional 1 & $81.33 \pm 0.75^{\mathrm{f}}$ & $43.16 \pm 0.30^{\mathrm{e}}$ & $76.56 \pm 0.84^{\mathrm{f}}$ & $28.45 \pm 0.40^{\text {cde }}$ & $4.76 \pm 0.13^{\mathrm{c}}$ & $14.71 \pm 0.24^{\text {ef }}$ \\
Conventional 2 & $74.41 \pm 0.86^{\mathrm{e}}$ & $44.39 \pm 0.86^{\mathrm{f}}$ & $69.74 \pm 0.66^{\mathrm{e}}$ & $27.57 \pm 0.66^{\mathrm{f}}$ & $4.67 \pm 0.21^{\mathrm{c}}$ & $16.83 \pm 1.25^{\mathrm{f}}$ \\
Conventional 3 & $80.40 \pm 0.85^{\mathrm{bc}}$ & $43.35 \pm 0.03^{\mathrm{d}}$ & $75.10 \pm 0.58^{\mathrm{ab}}$ & $26.48 \pm 0.37^{\mathrm{a}}$ & $5.30 \pm 0.28^{\mathrm{c}}$ & $17.17 \pm 0.91^{\text {def }}$ \\
Conventional 4 & $79.31 \pm 1.04^{\mathrm{d}}$ & $39.60 \pm 0.54^{\mathrm{cd}}$ & $73.98 \pm 1.14^{\mathrm{d}}$ & $26.38 \pm 0.12^{\mathrm{cd}}$ & $5.33 \pm 0.28^{\mathrm{c}}$ & $13.62 \pm 0.69^{\mathrm{bc}}$ \\
Conventional 5 & $78.24 \pm 1.01^{\mathrm{e}}$ & $40.79 \pm 0.78^{\mathrm{cd}}$ & $72.39 \pm 1.04^{\mathrm{de}}$ & $27.77 \pm 0.29^{\mathrm{de}}$ & $5.85 \pm 0.03^{\mathrm{c}}$ & $13.86 \pm 1.74^{\mathrm{b}}$ \\
Average & $\mathbf{7 8 . 7 4} \pm \mathbf{2 . 6 0}$ & $\mathbf{4 2 . 5 7} \pm \mathbf{1 . 8 4}$ & $\mathbf{7 3 . 5 5} \pm \mathbf{2 . 5 4}$ & $\mathbf{2 7 . 1 2} \pm \mathbf{0 . 7 5}$ & $\mathbf{5 . 1 8} \pm \mathbf{0 . 4 8}$ & $\mathbf{1 5 . 4 1} \pm \mathbf{1 . 8 5}$ \\
Organic 1 & $63.58 \pm 0.58^{\mathrm{a}}$ & $39.51 \pm 0.58^{\mathrm{bc}}$ & $59.14 \pm 0.77^{\mathrm{a}}$ & $27.17 \pm 0.33^{\mathrm{ab}}$ & $4.44 \pm 0.24^{\mathrm{c}}$ & $12.34 \pm 0.78^{\mathrm{bc}}$ \\
Organic 2 & $72.98 \pm 1.03^{\mathrm{de}}$ & $36.24 \pm 0.47^{\mathrm{a}}$ & $68.25 \pm 1.20^{\mathrm{de}}$ & $25.08 \pm 0.57^{\mathrm{bc}}$ & $4.73 \pm 0.36^{\mathrm{c}}$ & $11.16 \pm 0.51^{\mathrm{a}}$ \\
Organic 3 & $79.58 \pm 0.89^{\mathrm{ab}}$ & $41.47 \pm 0.35^{\mathrm{eb}}$ & $74.83 \pm 0.92^{\mathrm{ab}}$ & $28.94 \pm 0.69^{\mathrm{e}}$ & $4.75 \pm 0.20^{\mathrm{b}}$ & $12.53 \pm 0.75^{\mathrm{a}}$ \\
Organic 4 & $74.72 \pm 0.73^{\mathrm{bc}}$ & $42.35 \pm 0.32^{\mathrm{e}}$ & $70.08 \pm 0.80^{\mathrm{b}}$ & $27.63 \pm 0.62^{\mathrm{e}}$ & $4.65 \pm 0.09^{\mathrm{b}}$ & $14.72 \pm 0.92^{\mathrm{cd}}$ \\
Organic 5 & $74.34 \pm 0.80^{\mathrm{c}}$ & $42.35 \pm 0.26^{\mathrm{d}}$ & $69.81 \pm 1.03^{\mathrm{c}}$ & $27.00 \pm 0.17^{\mathrm{bcd}}$ & $4.53 \pm 0.27^{\mathrm{a}}$ & $15.35 \pm 0.19^{\mathrm{cd}}$ \\
Average & $\mathbf{7 3 . 0 4} \pm \mathbf{5 . 4 6}$ & $\mathbf{4 0 . 5 2} \pm \mathbf{2 . 7 2}$ & $\mathbf{6 8 . 4 2} \pm \mathbf{5 . 3 8}$ & $\mathbf{2 7 . 1 2} \pm \mathbf{1 . 5 4}$ & $\mathbf{4 . 6 2} \pm \mathbf{0 . 2 4}$ & $\mathbf{1 3 . 4 0} \pm \mathbf{1 . 6 8}$ \\
\hline
\end{tabular}

\footnotetext{
${ }^{\mathrm{a}-\mathrm{f}}$ Samples with same letter in the same group of treatment indicate that they were not significantly different at $\alpha=0.05$.
} 
IDF in rainy season crop $>$ dry season crops $(\mathrm{p}<0.05)$. However, for SDF values results indicate that rainy season crops $<$ dry season crops $(\mathrm{p}<0.05)$ (Figure 1$)$.

\subsection{Pectic Substances Content and Growing Season Effects}

In conventional fertilized waterleaf, pectin substances showed distinct ranges between the rainy and dry season crops ranging in values of $\sim 3.6-5$ and $5.4-6.2 \mathrm{~g} / 100 \mathrm{~g} \mathrm{dw}$, respectively. Similar trend was observed in organic fertilized waterleaf between rainy and dry season crops with range values of $\sim 3.1-4$ and $5.7-7.4 \mathrm{~g} / 100 \mathrm{~g} \mathrm{dw}$, respectively. In general there was no clear trend between different doses used in conventional or organic fertilization and the observed values corresponding to pectin substances (Table 4). When comparing the average values of all conventional and organic fertilized treatments we observe that values for pectin substances in rainy season crop $<$ dry season crops $(\mathrm{p}<0.05)$ (Figure 1 ).

In general, the average moisture content of Talinum triangulare (Jacq.) Willd in the present study was $90.39 \%$, which is within the range of $90 \%$ - 92\% previously reported for waterleaf (Rifai, 1994; Mensah et al., 2008). Since waterleaf is consumed fresh, we present the values for TDF, IDF, SDF (Table 5) and pectin substances on fresh weight basis as well, which show similar trend as those described above for conventional and organic fertilization based on dry basis (Table 4).

\subsection{Comparison of Dietary Fiber and Pectin Substances Content in Organic and Conventional Fertilized Waterleaf}

When comparing the average values of all conventional and organic fertilized treatments we observe that for TDF, IDF and SDF, the values in conventional crops $>$ organic crops $(\mathrm{p}<0.05)$. The only exception is IDF in dry season crops where there was no difference between both methods production $(\mathrm{p}>0.05)$ (Figure 1$)$. When comparing the average values of all conventional and organic fertilized treatments for pectin substances, we observe that values in conventional crops $>$ organic crops $(\mathrm{p}<0.05)$ in rainy season while the opposite trend in dry season ( $\mathrm{p}<0.05$ ) (Figure 1).

\section{Discussion}

During a dry season, plants experience water stress due to the limited rainfall and high light intensity. Mualim

Table 4. Pectic substance content of Talinum triangulare (Jacq.) Willd.

\begin{tabular}{|c|c|c|c|c|}
\hline \multirow{2}{*}{ Fertilizer } & \multicolumn{2}{|c|}{ Pectic Substances (g/100g dw) } & \multicolumn{2}{|c|}{ Pectic Substances (g/100g fw) } \\
\hline & Rainy season & Dry season & Rainy season & Dry season \\
\hline Conventional 1 & $4.13 \pm 0.02^{\mathrm{h}}$ & $5.42 \pm 0.10^{\mathrm{e}}$ & $0.40 \pm 0.00$ & $0.52 \pm 0.01$ \\
\hline Conventional 2 & $4.33 \pm 0.08^{f}$ & $6.20 \pm 0.09^{b}$ & $0.39 \pm 0.01$ & $0.60 \pm 0.01$ \\
\hline Conventional 3 & $4.23 \pm 0.07^{\mathrm{e}}$ & $6.28 \pm 0.19^{\mathrm{a}}$ & $0.36 \pm 0.00$ & $0.60 \pm 0.02$ \\
\hline Conventional 4 & $3.67 \pm 0.05^{\mathrm{d}}$ & $5.88 \pm 0.10^{\mathrm{b}}$ & $0.35 \pm 0.00$ & $0.56 \pm 0.01$ \\
\hline Conventional 5 & $5.00 \pm 0.01^{\mathrm{g}}$ & $6.25 \pm 0.00^{\mathrm{d}}$ & $0.52 \pm 0.00$ & $0.60 \pm 0.00$ \\
\hline Average & $4.27 \pm 0.44$ & $6.01 \pm 0.35$ & $0.40 \pm 0.06$ & $0.58 \pm 0.03$ \\
\hline Organic 1 & $3.16 \pm 0.02^{\mathrm{d}}$ & $5.77 \pm 0.15^{\mathrm{e}}$ & $0.28 \pm 0.00$ & $0.55 \pm 0.01$ \\
\hline Organic 2 & $3.73 \pm 0.07^{\mathrm{b}}$ & $6.89 \pm 0.05^{\mathrm{c}}$ & $0.35 \pm 0.01$ & $0.66 \pm 0.00$ \\
\hline Organic 3 & $3.87 \pm 0.01^{\mathrm{c}}$ & $7.47 \pm 0.04^{\mathrm{c}}$ & $0.37 \pm 0.00$ & $0.72 \pm 0.00$ \\
\hline Organic 4 & $4.05 \pm 0.04^{\mathrm{f}}$ & $7.03 \pm 0.16^{\mathrm{d}}$ & $0.43 \pm 0.00$ & $0.68 \pm 0.02$ \\
\hline Organic 5 & $3.37 \pm 0.00^{\mathrm{a}}$ & $5.76 \pm 0.07^{\mathrm{c}}$ & $0.33 \pm 0.00$ & $0.55 \pm 0.01$ \\
\hline Average & $3.64 \pm 0.34$ & $6.58 \pm 0.74$ & $0.35 \pm 0.05$ & $0.63 \pm 0.07$ \\
\hline
\end{tabular}

\footnotetext{
${ }^{\mathrm{a}-\mathrm{f}}$ Samples with same letter in the same group of treatment indicate that they were not significantly different at $\alpha=0.05$.
} 
Table 5. Dietary fiber content of Talinum triangulare (Jacq.) Willd in fresh weight.

\begin{tabular}{ccccccc}
\hline \multirow{2}{*}{ Fertilizer } & \multicolumn{2}{c}{ TDF $(\mathrm{g} / 100 \mathrm{~g} \mathrm{fw})$} & \multicolumn{2}{c}{ IDF $(\mathrm{g} / 100 \mathrm{~g} \mathrm{fw})$} & \multicolumn{2}{c}{ SDF $(\mathrm{g} / 100 \mathrm{~g} \mathrm{fw})$} \\
\cline { 2 - 6 } & Rainy season & Dry season & Rainy season & Dry season & Rainy season & Dry season \\
\hline Conventional 1 & $7.08 \pm 0.06$ & $4.15 \pm 0.03$ & $6.66 \pm 0.07$ & $2.73 \pm 0.04$ & $0.41 \pm 0.01$ & $1.41 \pm 0.02$ \\
Conventional 2 & $6.03 \pm 0.07$ & $4.27 \pm 0.08$ & $5.65 \pm 0.05$ & $2.65 \pm 0.06$ & $0.38 \pm 0.02$ & $1.62 \pm 0.12$ \\
Conventional 3 & $6.29 \pm 0.07$ & $4.19 \pm 0.07$ & $5.88 \pm 0.04$ & $2.54 \pm 0.04$ & $0.41 \pm 0.02$ & $1.65 \pm 0.09$ \\
Conventional 4 & $6.93 \pm 0.09$ & $3.84 \pm 0.07$ & $6.46 \pm 0.10$ & $2.53 \pm 0.01$ & $0.46 \pm 0.02$ & $1.31 \pm 0.07$ \\
Conventional 5 & $7.35 \pm 0.10$ & $4.00 \pm 0.17$ & $6.80 \pm 0.10$ & $2.67 \pm 0.03$ & $0.55 \pm 0.00$ & $1.33 \pm 0.17$ \\
Average & $\mathbf{6 . 7 4} \pm \mathbf{0 . 5 2}$ & $\mathbf{4 . 0 9} \pm \mathbf{0 . 1 9}$ & $\mathbf{6 . 2 9} \pm \mathbf{0 . 4 7}$ & $\mathbf{2 . 6 0} \pm \mathbf{0 . 0 7}$ & $\mathbf{0 . 4 4} \pm \mathbf{0 . 0 6}$ & $\mathbf{1 . 4 9} \pm \mathbf{0 . 1 7}$ \\
Organic 1 & $5.08 \pm 0.05$ & $3.80 \pm 0.07$ & $4.72 \pm 0.06$ & $2.61 \pm 0.03$ & $0.35 \pm 0.02$ & $1.19 \pm 0.08$ \\
Organic 2 & $6.22 \pm 0.09$ & $3.48 \pm 0.05$ & $5.81 \pm 0.10$ & $2.41 \pm 0.05$ & $0.40 \pm 0.03$ & $1.07 \pm 0.05$ \\
Organic 3 & $6.92 \pm 0.08$ & $3.99 \pm 0.03$ & $6.51 \pm 0.08$ & $2.78 \pm 0.07$ & $0.41 \pm 0.02$ & $1.20 \pm 0.07$ \\
Organic 4 & $7.12 \pm 0.07$ & $4.07 \pm 0.03$ & $6.67 \pm 0.08$ & $2.66 \pm 0.06$ & $0.44 \pm 0.01$ & $1.41 \pm 0.09$ \\
Organic 5 & $6.49 \pm 0.07$ & $4.07 \pm 0.03$ & $6.10 \pm 0.09$ & $2.59 \pm 0.02$ & $0.40 \pm 0.02$ & $1.48 \pm 0.02$ \\
Average & $\mathbf{6 . 3 6} \pm \mathbf{0 . 7 4}$ & $\mathbf{3 . 8 8} \pm \mathbf{0 . 2 6}$ & $\mathbf{5 . 9 6} \pm \mathbf{0 . 7 2}$ & $\mathbf{2 . 6 1} \pm \mathbf{0 . 1 5}$ & $\mathbf{0 . 4 0} \pm \mathbf{0 . 0 3}$ & $\mathbf{1 . 2 8} \pm \mathbf{0 . 1 6}$ \\
\hline
\end{tabular}

[14] reported that waterleaf in dry season have significantly lower chlorophyll content than the rainy season possibly due to a low supply of nutrients (including $\mathrm{N}$ ) and substrate competition. Thus, the substrate for complex compound like dietary fiber may decrease causing low levels of dietary fiber such as TDF and IDF in the dry season waterleaf as observed in the present study. Another adaptation mechanism of plants in response to abiotic stress is by undergoing osmotic adjustment. This is done by accumulating compatible solutes, such as sucrose, amino acid (proline and glycine betaine), sorbitol, mannitol, and inositol and its derivatives [20]-[22]. The transgenic tobacco (Nicotina tabacum) that accumulates D-ononitol showed less photosynthesis inhibition in salinity and water stress condition [22]. Inositol, D-ononitol, and D-pinitol protect the plant by protecting the cell structure againts radical oxygen species (ROS) and controlling the cell turgor pressure [22]. Inositol is a precursor of dietary fibers. Inositol will be oxydized into UDP-D-galacturonic and other sugar UDP, like UDP-glucuronic and UDP-L-arabinose [21]. The glucuronic compound is a precursor of many soluble dietary fiber like hemicellulose, gum, mucilage, and pectin. The inositol accumulation will possibly lead the plants to synthesize more SDF, including pectic substances, in dry season waterleaf compared to rainy season crops as observed in the present study.

The proportion of dietary fiber varies among many vegetables, affected by some factors including level of maturation, part of plant to be consumed, and cultivation practices [23]. Compared to other common vegetables in Indonesia, TDF and IDF contents of waterleaf dry season crops are relatively low (Table 6) whereas TDF and IDF contents in waterleaf rainy season crops are above most vegetables. When consumed regularly, waterleaf may contribute with a significant amount of dietary fiber to the diet. FDA recommends a daily diet containing $25 \mathrm{~g}$ of dietary fiber for adult women and $38 \mathrm{~g}$ for adult men. The present study shows that $100 \mathrm{~g}$ of waterleaf dry season crops will supply $\sim 3.89$ - 4.09 g of dietary fiber and contribute to fulfill $\sim 10 \%-16 \%$ of TDF needs and $~ 9 \%-13.9 \%$ of IDF needs per day. On the other hand, 100g of waterleaf rainy season crops, with its high TDF and IDF content, will contribute to fulfill $17 \%$ - 26\% of TDF needs and $21.3 \%$ - 32.6\% of IDF needs per day.

In relation to SDF, waterleaf dry season crops contain the highest SDF content compared to most vegetables (Table 6). In previous reports, a meta-analysis on 67 studies focusing on SDF, showed that there was a significant reduction in serum cholesterol with increased dietary fiber intake [24]. It was further reported that $2-10 \mathrm{~g}$ consumtion of dietary fiber per day can reduce total serum cholesterol and LDL-cholesterol concentration. Accordingly, $200 \mathrm{~g}$ of waterleaf dry season crops could supply $\sim 2.8 \mathrm{~g}$ of SDF, which is within the range needed to potentially reduce blood cholesterol levels. Thus, the recommended daily consumption of waterleaf is $200 \mathrm{~g}$ 
Table 6. Dietary fiber content of common vegetables in Indonesia.

\begin{tabular}{|c|c|c|c|c|c|}
\hline \multirow{2}{*}{ Vegetable } & \multirow{2}{*}{ Scientific name } & \multirow{2}{*}{ Method } & \multicolumn{3}{|c|}{ Dietary fiber content (g/100g dw) } \\
\hline & & & TDF & IDF & SDF \\
\hline Peanut $^{\mathrm{a}}$ & Arachis hypogaea L. & Asp, 1995 & $10.91 \pm 2.84$ & $9.63 \pm 2.50$ & $1.18 \pm 0.24$ \\
\hline Pods ${ }^{\mathrm{b}}$ & Pisum sativum & AOAC, 1983 & $13.17 \pm 1.64$ & $11.31 \pm 1.51$ & $1.86 \pm 0.86$ \\
\hline Carrot $^{\mathrm{c}}$ & Daucus carota $\mathrm{L}$. & AOAC, 1990 & $26.78 \pm 1.13$ & $10.46 \pm 1.26$ & $16.32 \pm 4.79$ \\
\hline Green tomato $^{\mathrm{d}}$ & Solanum lycopersicum & Asp, 1983 & $32.84 \pm 0.23$ & $25.22 \pm 0.47$ & $7.62 \pm 0.24$ \\
\hline Genjer $^{\mathrm{d}}$ & Limnocharis flava & Asp, 1983 & $39.38 \pm 1.29$ & $31.74 \pm 0.94$ & $7.62 \pm 0.35$ \\
\hline Soybean $1^{\mathrm{e}}$ & Glycine max (L.) & Asp, 1992 & $35.22 \pm 0.23$ & $30.43 \pm 0.25$ & $4.79 \pm 1.98$ \\
\hline $\begin{array}{l}\text { Organically fertilized } \\
\text { waterleaf (dry season) }\end{array}$ & $\begin{array}{c}\text { Talinum triangulare (Jacq.) } \\
\text { Willd }\end{array}$ & AOAC, 1999 & $40.52 \pm 2.72$ & $27.12 \pm 1.54$ & $13.40 \pm 1.68$ \\
\hline $\begin{array}{l}\text { Conventionally fertilized } \\
\text { waterleaf (dry season) }\end{array}$ & $\begin{array}{c}\text { Talinum triangulare (Jacq.) } \\
\text { Willd }\end{array}$ & AOAC, 1999 & $42.57 \pm 1.84$ & $27.12 \pm 0.75$ & $15.41 \pm 1.85$ \\
\hline Cashew nut leaves $^{\mathrm{d}}$ & Anacardium occidentale L. & Asp, 1983 & $45.64 \pm 1.29$ & $39.98 \pm 0.20$ & $5.66 \pm 1.09$ \\
\hline Sweet potato leaves ${ }^{\mathrm{d}}$ & Ipomoea batatas & Asp, 1983 & $46.66 \pm 1.41$ & $39.82 \pm 0.28$ & $6.82 \pm 0.56$ \\
\hline Bitter cucumber $^{\mathrm{d}}$ & Momordica charantia & Asp, 1983 & $49.34 \pm 1.09$ & $42.96 \pm 0.35$ & $6.38 \pm 0.42$ \\
\hline Sweet basil leaves $^{\mathrm{d}}$ & Ocinum bassilicum ferina citratum & Asp, 1983 & $50.63 \pm 0.89$ & $43.51 \pm 2.00$ & $7.12 \pm 1.11$ \\
\hline Cassava leaves $^{\mathrm{d}}$ & Manihot utilissima & Asp, 1983 & $52.26 \pm 2.72$ & $43.03 \pm 2.74$ & $9.23 \pm 0.01$ \\
\hline Melinjo leaves $^{\mathrm{d}}$ & Gnetum gnemon & Asp, 1983 & $57.45 \pm 0.16$ & $48.69 \pm 0.25$ & $876 \pm 0.09$ \\
\hline Papaya leaves $^{\mathrm{d}}$ & Carica papaya & Asp, 1983 & $57.46 \pm 2.26$ & $48.75 \pm 0.35$ & $8.71 \pm 0.49$ \\
\hline Soybean $2^{\mathrm{e}}$ & Glycine max (L.) & AOAC, 1999 & $59.42 \pm 0.10$ & $57.65 \pm 0.23$ & $1.31 \pm 0.02$ \\
\hline Ferns $^{\mathrm{d}}$ & Cycas rumphii & Asp, 1983 & $60.97 \pm 0.52$ & $53.64 \pm 0.81$ & $7.33 \pm 0.25$ \\
\hline Poh-pohan ${ }^{\mathrm{d}}$ & Pilea trinervia & Asp, 1983 & $67.03 \pm 0.44$ & $57.04 \pm 0.25$ & $9.99 \pm 0.15$ \\
\hline Beluntas $^{\mathrm{d}}$ & Pluchea indica & Asp, 1983 & $70.26 \pm 1.06$ & $67.29 \pm 1.09$ & $2.97 \pm 0.03$ \\
\hline $\begin{array}{c}\text { Organically fertilized } \\
\text { waterleaf (rainy season) }\end{array}$ & $\begin{array}{c}\text { Talinum triangulare (Jacq.) } \\
\text { Willd }\end{array}$ & AOAC, 1999 & $73.04 \pm 5.46$ & $68.42 \pm 5.38$ & $4.62 \pm 0.24$ \\
\hline $\begin{array}{l}\text { Conventionally fertilized } \\
\text { waterleaf (rainy season) }\end{array}$ & $\begin{array}{c}\text { Talinum triangulare (Jacq.) } \\
\text { Willd }\end{array}$ & AOAC, 1999 & $78.74 \pm 2.60$ & $73.55 \pm 2.54$ & $5.18 \pm 0.48$ \\
\hline
\end{tabular}

${ }^{\mathrm{a}}[29],{ }^{\mathrm{b}}[30],{ }^{\mathrm{c}}[31],{ }^{\mathrm{d}}[32],{ }^{\mathrm{e}}[33]$.

fresh weight/ day with serving size of $100 \mathrm{~g}$ fresh waterleaf. From dry season waterleaf, this amount will fulfill $20 \%-32 \%$ of TDF daily needs and 36\% - 55\% SDF daily needs. We need to combine with other food to fulfill the dietary fiber needs completely.

In relation to pectin, waterleaf dry season crops are a rich source of pectin substances. Compared to the pectin level of many fruits and vegetables [25], the pectin level in waterleaf rainy season crops $(0.58-0.63 \mathrm{~g} / 100 \mathrm{~g} \mathrm{fw})$ is higher than pectin levels in longan fruit $(0.34 \mathrm{~g} / 100 \mathrm{~g} f \mathrm{f})$, raspberry $(0.34 \mathrm{~g} / 100 \mathrm{~g} \mathrm{fw})$, apple $(0.39-0.49$ $\mathrm{g} / 100 \mathrm{~g} \mathrm{fw})$, legumes $(0.43-0.63 \mathrm{~g} / 100 \mathrm{~g} \mathrm{fw})$, orange $(0.57 \mathrm{~g} / 100 \mathrm{~g} \mathrm{fw})$, and sweet potato $(0.61 \mathrm{~g} / 100 \mathrm{~g} \mathrm{fw})$ among others. Several studies have reported that pectin as part of SDF has the ability to reduce blood cholesterol [26]-[28]. Baker [28] reported in in-vivo studies that pectin levels of $0.23 \mathrm{~g} / 100 \mathrm{~g}$ from citrus orange mixed into the diet could reduce LDL level of rats by $5 \%$ and decrease the glucose response. Thus, waterleaf due to its high pectin content could be considered a good source of pectin substances for these biological activities.

\section{Conclusions}

In the present study, we reported that season growing conditions for waterleaf had a large effect on TDF, IDF, 
SDF and pectin substances content. For example, waterleaf rainy season crops had larger levels of TDF, IDF than waterleaf dry season crops, while the latter had higher levels of SDF and pectin substances than the former.

On the other hand, despite that there were statistically differences between conventionally and organically fertilized waterleaf crops in relation to TDF, IDF, SDF and pectin substances, these differences were minimal and would not make a major difference in the contribution to the diet.

According to our results, diets which could include 100 - $200 \mathrm{~g}$ of waterleaf rainy season crops would significantly contribute to the recommended levels of daily intake of TDF and IDF, while 100 - $200 \mathrm{~g}$ of waterleaf dry season crops would significantly contribute to the recommended levels of daily intake of SDF and pectin substances.

\section{Acknowledgements}

This publication was produced under USAID Cooperative Agreement No. AID-497-A-11-00003. This report is made possible by the generous support of the American people through the United States Agency for International Development (USAID). The contents are the responsibility of Bogor Agricultural University \& Texas A\&M Borlaug Institute for International Agriculture, and do not necessarily reflect the views of USAID or the United States Government.

\section{References}

[1] Andarwulan, N., Batari, R., Sandrasari, D.A., Bolling, B. and Wijaya, H. (2010) Flavonoid Content and Antioxidant Activity of Vegetables from Indonesia. Journal of Food Chemistry, 121, 1231-1235. http://dx.doi.org/10.1016/j.foodchem.2010.01.033

[2] Benbrook, C.H., Zhao, X., Yanez, J., Davies, N. and Andrews, P. (2008) New Evidence Confirms the Nutritional Superiority of Plant-Based Organic Foods. State of Science Review. www.organic-center.org

[3] Carbonaro, M., Mattera, M., Nicoli, S., Bergamo, P. and Cappelloni, M. (2002) Modulation of Antioxidant Compounds in Organic vs. Conventional Fruit (Peach Prunus persica L., and Pear Pyrus communis L.). Journal of Agriculture and Food Chemistry, 50, 9-11. http://dx.doi.org/10.1021/jf0202584

[4] Young, J.E., Zhao, X., Carey, E.E., Welti, R., Yang, S. and Wang, W. (2005) Phytochemical Phenolics in Organically Grown Vegetables. Molecular Nutrition \& Food Research, 49, 1136-1142. http://dx.doi.org/10.1002/mnfr.200500080

[5] Abu-Zahra, T.R., Al-Ismail, K. and Shatat, F. (2007) Effect of Organic and Conventional Systems on Fruit Quality of Strawberry (Fragaria $\times$ ananassa duch) Grown under Plastic House Conditions in the Jordan Valley. Acta Horticulture (ISHS), 741, 159-171.

[6] Ren, H., Endo, H. and Hayashi, T. (2001) Antioxidative and Antimutagenic Activities and Polyphenol Content of Pesticide-Free and Organically Cultivated Green Vegetables Using Water-Soluble Chitosan as a Soil Modifier and Leaf Surface Spray. Journal of the Science of Food and Agriculture, 81, 1426-1432. http://dx.doi.org/10.1002/jsfa.955

[7] Worthington, V. (2001) Nutritional Quality of Organic Versus Conventional Fruits, Vegetables, and Grains. Journal of Alternative and Complementary Medicine, 7, 161-173. http://dx.doi.org/10.1089/107555301750164244

[8] Hallmann, E. and Rembiałkowska, E. (2006) Antioxidant Compounds Content in Selected Onion Bulbs from Organic and Conventional Cultivation. Journal of Research and Applications in Agricultural Engineering, 51, 42-46.

[9] Wang, Z.H., Li, S.X. and Malhi, S. (2008) Review: Effects of Fertilization and Other Agronomic Measures in Nutritional Quality of Crops. Journal of the Science of Food and Agriculture, 88, 7-23. http://dx.doi.org/10.1002/jsfa.3084

[10] Moore, J.E. (1994) Forage Quality Indices: Development and Application. In: Fahey, G.C., Ed., Forage Quality, Evaluation, and Utilization, ASA, CSSA, and SSSA, Madison, 967-998.

[11] Eppendorfer, W.H. and Eggum, B.O. (1996) Fertilizer Effects on Yield, Mineral and Amino Acid Composition, Dietary Fiber and Nutritive Value of Leeks. Plant Foods for Human Nutrition, 49, 163-174. http://dx.doi.org/10.1007/BF01091974

[12] Siatka, T. and Kasparova, M. (2010) Seasonal Variation in Total Phenolic and Flavonoid Contents and DPPH Scavenging Activity of Bellis perennis L. Flowers. Molecules, 15, 9450-9461. http://dx.doi.org/10.3390/molecules15129450

[13] Marsic, N.K., Gasperli, L., Abram, V., Budic, M. and Vidrih, R. (2011) Quality Parameters and Total Phenolic Content in Tomato Fruits Regarding Cultivar and Microclimatic Conditions. Turkish Journal of Agriculture and Forestry, 35, 185-194.

[14] Mualim, L. (2012) Produksi dan Kualitas Kolesom dengan Pemupukan Organik dan Inorganik. Dissertation, Faculty of 
Agriculture, Bogor Agricultural University, Bogor.

[15] Association of Official Analytical Chemist (AOAC) Official Method 991.42 (2012) Official Methods of Analysis of the Association of Official Analytical Chemist. AOAC Inc., Arlington, Virginia.

[16] Association of Official Analytical Chemist (AOAC) Official Method 985.29 (2012) Official Methods of Analysis of the Association of Official Analytical Chemist. AOAC Inc., Arlington, Virginia.

[17] Association of Official Analytical Chemist (AOAC) Official Method 991.42 (2012) Official Methods of Analysis of the Association of Official Analytical Chemist. AOAC Inc., Arlington, Virginia.

[18] McCready, R.M. and McComb (1965) Extraction of the Pectin from the Citrus Peels and Preservation of Pectin to Pectic Acid. Method Carbohydrate Chemistry, 8, 167-170.

[19] Blumenkrantz, N. and Asboe-Hansen, G. (1973) New Method for Quantitative Determination of Uronic Acid. Analytical Biochemistry, 54, 484-489. http://dx.doi.org/10.1016/0003-2697(73)90377-1

[20] Morgan, J.M. (1984) Osmoregulation and Water Stress in Higher Plants. Annual Review of Plant Physiology, 35, 299319. http://dx.doi.org/10.1146/annurev.pp.35.060184.001503

[21] Styer, J.C. (2000) Regulating Inositol Biosynthesis in Plants: Myo-Inositol Synthase and Myo-Inositol Phosphatase. Thesis, Faculty of Virginia Polytechnic Institute and State University, Blacksburg.

[22] Sheveleva, E., Chmara, W., Bohnert, H.J. and Jensen, R.G. (1997) Increased Salt and Drought Tolerance by D-Ononitol Production in Transgenic Nicotiana tabacum L. Plant Physiology, 115, 1211-1219.

[23] Anderson, N.E. and Clydesdale, F.M. (1980) Effects of Processing on the Dietary Fiber Content of Wheat Bran, Pureed Green Beans and Carrots. Journal of Food Science, 45, 1533-1537. http://dx.doi.org/10.1111/j.1365-2621.1980.tb07556.x

[24] Brown, L., Rosner, B., Willett, W.W. and Sacks, F.M. (1999) Cholesterol-Lowering Effects of Dietary Fiber: A MetaAnalysis. American Journal of Clinical Nutrition, 69, 30-42.

[25] Baker, R.A. (1997) Reassessment of Some Fruit and Vegetables Pectin Levels. Journal of Food Science, 62, $225-229$. http://dx.doi.org/10.1111/j.1365-2621.1997.tb03973.x

[26] Story, J.A. and Kritchevsky, D. (1978) Fiber, Hypercholesteremia, and Atherosclerosis. Lipids, 13, 366-369. http://dx.doi.org/10.1007/BF02533731

[27] Hunninghake, D.B., Miller, V.T., Larosa, J.C., Kinosian, B., Brown, V., Howard, W.J., et al. (1994) Hypocholesterolemic Effects of a Dietary Fiber Supplement. American Journal of Clinical Nutrition, 59, 1050-1054.

[28] Baker, R.A. (1994) Potential Dietary Benefits of Citrus Pectin and Fiber. Food Technology, 48, 133-139.

[29] Kutoz, T., Golob, T., Kač, M. and Plestenjak, A. (2003) Dietary Fiber Content of Dry and Processed Beans. Food Chemistry, 80, 231-235. http://dx.doi.org/10.1016/S0308-8146(02)00258-3

[30] Stoughton-Ens, M.D., Hatcher, D.W., Wang, N. and Warkentin, T.D. (2009) Influence of Genotype and Environment on the Dietary Fiber Content of Field Pea (Pisum sativum L.) Grown in Canada. Food Research International, 43, 547552. http://dx.doi.org/10.1016/j.foodres.2009.07.011

[31] Englyst, H.N. and Hudson, G.J. (1996) The Classification and Measurement of Dietary Carbohydrates. Food Chemistry, 57, 15-21. http://dx.doi.org/10.1016/0308-8146(96)00056-8

[32] Desminarti, S. (2001) Kajian serat pangan dan antioksidan alami beberapa jenis sayuran serta daya serap dan retensi antioksidan pada tikus percobaan. Thesis, Faculty of Agricultural Technology, Bogor Agricultural University, Bogor.

[33] Jelita, K. (2011) Verifikasi metode analisis serat pangan dengan metode AOAC dan Asp terhadap parameter repeatability, selektivitas, dan ruggedness. Thesis, Faculty of Agricultural Technology, Bogor Agricultural Technology, Bogor. 
Scientific Research Publishing (SCIRP) is one of the largest Open Access journal publishers. It is currently publishing more than 200 open access, online, peer-reviewed journals covering a wide range of academic disciplines. SCIRP serves the worldwide academic communities and contributes to the progress and application of science with its publication.

Other selected journals from SCIRP are listed as below. Submit your manuscript to us via either submit@scirp.org or Online Submission Portal.
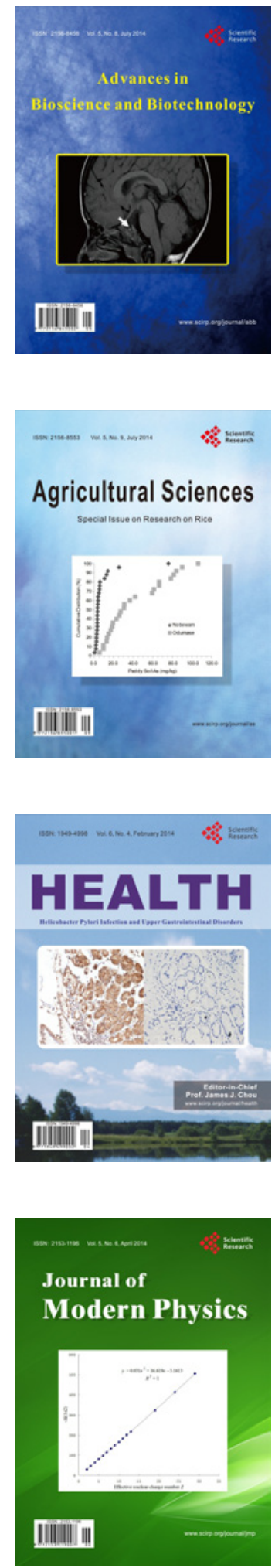
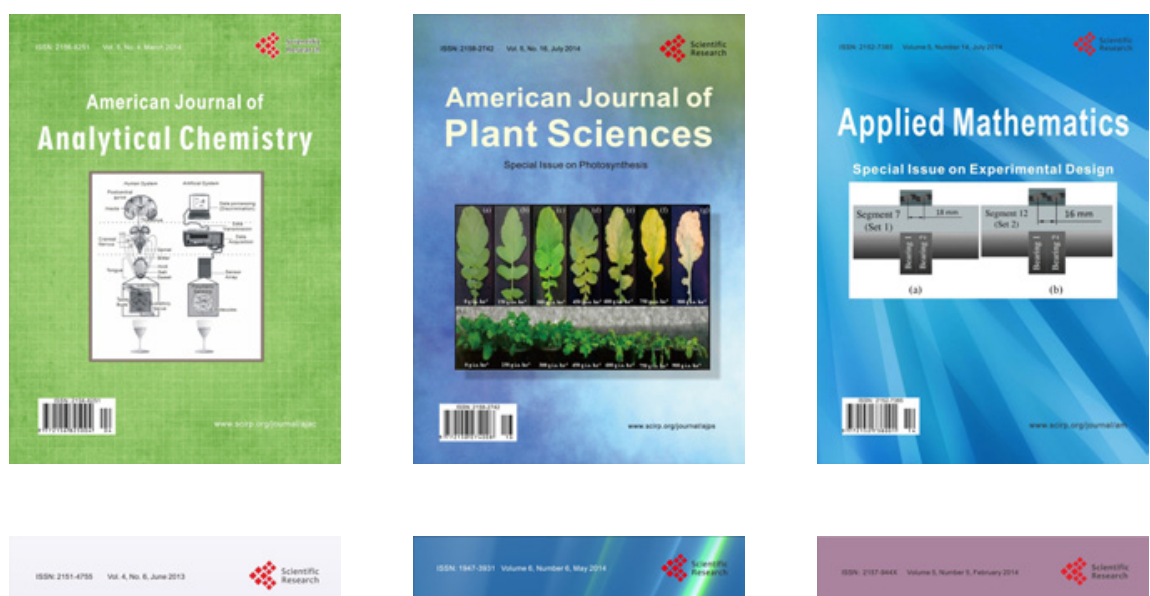

Creative Education
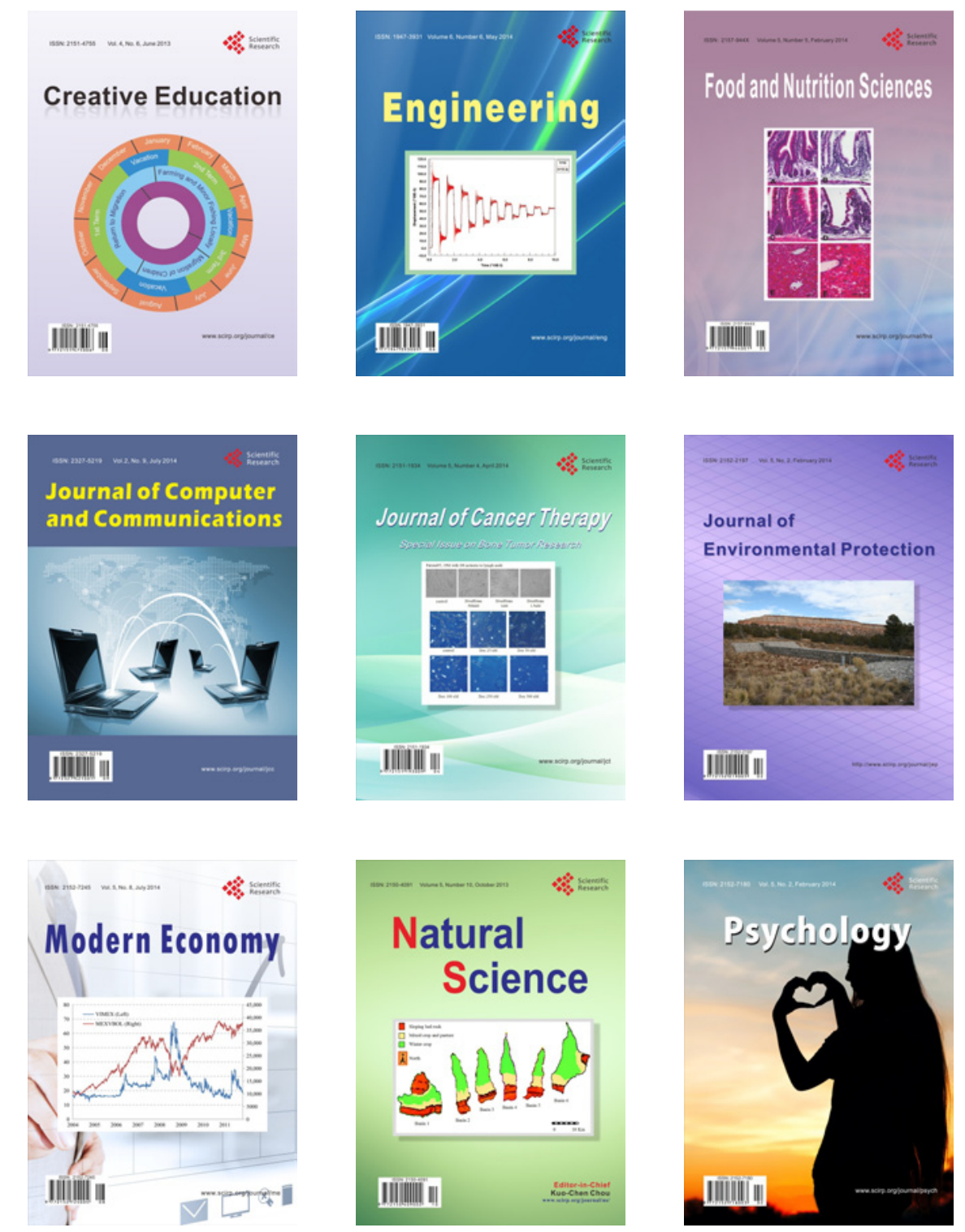